\title{
NOSTALGIA, GUERRA CIVIL Y FRANQUISMO EN LA NARRATIVA ESPAÑOLA DE FINALES DEL SIGLO XX
}

\author{
Marianela Muñoz
}

\begin{abstract}
RESUMEN
Este artículo pretende analizar la actitud nostálgica en el retorno al pasado, concretamente a los años de la Guerra Civil y el franquismo, como una tendencia de la narrativa española de la década de los ochenta y noventa. La memoria ingresa en el ámbito ficcional, construyendo un imaginario ambivalente acerca de los hechos de la Guerra Civil y la posguerra española y su ingerencia en el hoy. La puesta en escrito del recuerdo, según Freud, no puede evitar su cuota de fantaseo cuando se trata de los recuerdos de infancia; para Navajas, esta misma puesta en escrito del recuerdo no puede evitar su labor de desmitificación cuando se trata del tiempo de guerra. De esta forma, los textos disuelven la frontera entre la memoria personal y colectiva.

Palabras clave: Literatura española contemporánea, nostalgia, Guerra Civil española, Franquismo, memoria histórica.
\end{abstract}

\begin{abstract}
In this article one will attempt to analyze how with a nostalgic attitude the Spanish narrative of the 80's and 90's returns to the past: the Spanish Civil War years and the Franco era.

There is a place for memory in this literature where the valuation of the facts has a double meaning. These texts dissolve the limits between personal and collective memory, upon reviewing and writing the period of the infant years, ("day dreams" for Freud or "gold age" for Bachelard) with its equivalence to the time of the Spanish War and Post War ("demythologization" for Navajas).

Key words: Spanish contemporary literature, nostalgia, Spanish civil war, Franco era, historic memory.
\end{abstract}

\section{Introducción}

Un acontecimiento político, bélico, social y económico, como la Guerra Civil o la Dictadura, marca con heridas profundas, recuerdos y sangre una y varias generaciones. Los escritores de la narrativa española de los últimos veinte años del siglo XX, por diversas razones

ML. Marianela Muñoz. Profesora de la Escuela de Filología, Lingüística y Literatura de la Universidad de Costa Rica. San Pedro, San José, Costa Rica.

Correo electrónico: redaccionespanola@yahoo.com

Recepción: 16- 6- 2008

Aceptación: 11- 7- 2008 
y de diversas formas reviven estas experiencias. El dolor, los odios, el exilio, la represión constituyen temas frecuentes en las conversaciones españolas y los textos literarios no escapan a esas memorias ${ }^{1}$.

Si bien en la época de la transición democrática (1975- 1982), la narrativa española manifestó una pretendida ruptura con cualquier alusión a la Guerra Civil o a la Dictadura; luego este rechazo es superado pues, al menos en cierto sector, surge un interés por reinterpretar ese pasado, esta vez desde un distanciamiento que pretende ser objetivo, sin ignorar que la ingerencia de estos años aún se manifiesta en el devenir social de la nación.

Según Sobejano, toda novela perdurable, ya se incline al testimonio, o sea, a la novela histórica del presente irrepetible (como ocurrirá cuando apremien el hambre, la guerra, la enfermedad, la muerte y el silencio opresor) tiene, además de su propia verificabilidad (la inmanente al texto), un horizonte de verificación total: el de la realidad histórica de la que brotó con el estremecimiento germinativo de lo que es -a un tiempo- necesario y libre (2003: 118). En este espacio y con un objetivo aleccionador como referencia, debe hablarse de lo acontecido, debe nombrarse lo silenciado y debe rescatarse lo olvidado.

Dicha intención se verifica en la narrativa española de finales del siglo XX, también llamada "nueva narrativa" o "neo novela". Se plantea que la mirada nostálgica del pasado ante la Guerra Civil española y los años del franquismo dialoga incluso con el presente, en un camino de construcción de identidad y hasta con el futuro, en una clave de posibilidad. Así, un retorno al tiempo anterior no resulta fortuito, si no más bien, asertivo.

\section{Tematización del pasado de la Guerra Civil y la posguerra española en la narrativa de los ochenta y noventa}

La historia española de los últimos treinta años suscita una serie de lecturas cuya complejidad trasciende tanto la crisis del individuo, como la crisis de la propia España. Se trata de una época plagada de mitos, proyectos radicales, cambios e inestabilidad cuyo efecto sobre el conjunto de escritores, resulta multiplicado por la pluralidad de voces que intentan desentrañar su significado.

Tomando como ejemplo el tema de la guerra de carácter civil, según Maryse Bertrand de Muñoz (1994: 427) hasta 1993 se contabilizan más de 1300 novelas en Occidente. En cuanto a la Guerra Civil española, o los años posteriores a ella, la nueva consideración pretende no sólo un retreat in to the past o un revival. Se trata de un fenómeno que, arremetiendo contra diversos mitos, se inscribe dentro de "las complejas relaciones de España con el pasado y las preguntas problemáticas de la identidad y de la autodefinición en el contexto confuso y contradictorio del mundo postmoderno" (Morgan 1995: 164).

En este sentido, la tematización sobre el pasado de la Guerra Civil y primeros años de la posguerra española ha llamado la atención de algunos estudiosos de la literatura y han sido consideradas como componentes de una nueva configuración epistémica, "para después del posmodernismo", en el discurrir de la "reciente novela española":

\footnotetext{
Un aspecto que ya había señalado Gonzalo Sobejano como característica de la novela de los años setenta, el uso de la memoria, alcanza hoy día una importancia básica en la narrativa. En un artículo publicado en marzo de este año [1987], refiriéndose al curso de la novela en 1984, apuntaba el predominio absoluto "de la memoria y la reflexión sobre el pasado, tanto personal como colectivo" (Amell 1987: 190).
} 
Varios autores, entre quienes se encuentran G. Navajas, G. Sobejano, R. Morgan, apuntan a la identificación de una serie de características en la llamada nueva narrativa española, correspondiente al segmento definido entre la década de los ochenta y noventa ${ }^{2}$.

Navajas señala que quizás uno de los elementos diferenciadores de esta corriente radica en una nueva posición ante el pasado. Anteriormente, hubo un desapego por los temas del pasado que pudieran remitir a la época de Franco o a la caída de la Segunda República; de ahí, la novedad en la emergencia de este tópico y, por ende, la conformación de un nuevo grupo:

Se plantea, entonces, cómo una de las tendencias de esta nueva estética (Navajas 1993: 105- 130) consiste en la reconsideración de épocas pretéritas como su opción temática, elemento cuyo valor se redefine a partir de nuevas posturas, las cuales dejan de lado su rechazo radical para, más bien, abrir paso a una actitud nostálgica, en donde la conexión con ese pasado pretende, ya sea la afirmación de los recuerdos o bien, la desmitificación de sus paradigmas.

De una u otra forma se entrecruzan variables histórico- políticas con motivaciones particulares. Memoria histórica ${ }^{3}$ y memoria personal dialogan en un debate de interpretación y asignación de sentido de una época concreta.

Ahora bien, en este movimiento rememorativo surge un problema de ambivalencia, donde las posturas ante la posguerra son diversas y hasta encontradizas. Nos hallamos ante los límites entre la memoria personal (la infancia, la casa natal o la juventud de los escritores) y la memoria histórica, como un trasfondo colectivo de la propia circunstancia española; de ahí la plurivocidad de sus valoraciones.

\section{La ambivalencia del fenómeno de la nostalgia: una aproximación teórica}

Como fenómeno social, cabe decir, en primera instancia, que la nostalgia es una reconstrucción del pasado, la cual se basa tanto en la memoria como en la ficción, pues la memoria no es capaz de recordar cada detalle de cuanto aconteció y la fantasía reemplaza las "piezas faltantes" del segmento que se intenta reproducir. Tal definición corresponde a la síntesis que precede el artículo titulado “Acerca de la nostalgia”, de Darío Rodríguez (1990: 11- 29).

Allí se añade, además, que la nostalgia aparece en medio de circunstancias de cambio social: "when the future becomes uncertain or when it is perceived as unpleasant" (1990: 11); en este sentido, la valoración del pasado se efectúa a partir del reconocimiento de un periodo anterior donde las alternativas que se vislumbraban para el futuro, esto es el presente actual, suponían toda una serie de oportunidades y sensaciones de mejoramiento y bienestar, las cuales no han sido del todo consumadas:

\footnotetext{
El fenómeno de la nostalgia se encuentra estrechamente relacionado con el tiempo, con la percepción de pasados. Es importante, sin embargo, considerar que no se trata necesariamente de un pasado histórico, fáctico sino de pasados posibles o -mejor dicho- de un pasado que es reconstruido en el presente de tal forma que la evaluación de determinados sucesos ocurridos se produce en la reelaboración presente de los presentes pasados en la medida de la posibilidad. En otras palabras, se produce una comparación de los sucesos pasados con las otras alternativas no actualizadas y que existían como posibilidad en el pasado (Rodríguez 1990:14).
}

La nostalgia, según Rodríguez, abarcaría diversas dimensiones, una temporal, por el pasado; una social, por las relaciones con otras personas; o una material, por la cual "se puede sentir nostalgia por situaciones, lugares, objetos" (1990: 11). A partir de estos elementos, se establece un juego de potenciales, donde se desencadena un proceso de reflexión, de reconstrucción de sentido, donde una situación pasada, cuyo sentido es negado, resulta reevaluada. 
Las propuestas de Darío Rodríguez apuntan el fenómeno nostálgico como una reconstrucción de posibilidades, por cuanto la atención de los sistemas psíquicos y sociales se vuelca, una y otra vez, sobre la indagación de una situación pasada y la proyección de sus secuelas; por eso, en ocasiones se considera una especie de "negación":

La comunicación de la nostalgia es aquella que transmite una consideración temporal con un sentido diferente al que está definiendo el presente presente. Se traduce en una invitación a redescubrir las posibilidades del pasado negando las que fueron actualizadas (Rodríguez 1990: 17).

La actualización del segmento en cuestión, donde se abren las posibilidades que fueron futuras y ya pasaron, se hace desde el conocimiento de uno de los resultados, el cual es rechazado, en primera instancia, para considerar otro, con diferente evolución; es decir, el plausible, una vez que la complejidad de los elementos en juego ha sido reducida, en parte, gracias al devenir temporal. Así, se efectúa una reelaboración, la cual es, a la vez, un proceso de reflexión, de autotematización y de autorreferencia.

Cuando el fenómeno de la nostalgia trasciende además el hecho individual y participa de un acto comunicativo, se comprende que este intento-relectura pretende generar una modificación compartida- social de sentido; esta faceta es identificada por Rodríguez como "comunicación de la nostalgia" (1990:18). Tal sería el caso del acto de escritura en general y de la tendencia de la narrativa española de fin de siglo, en particular.

La relación entre los recuerdos y la literatura ya había sido señalada por Sigmund Freud (1954: 50), cuando describía la actividad del poeta como "fantaseo", asimilándola a cuanto crea un niño al jugar. El poeta asigna grandes magnitudes de afecto a ese mundo fantástico, creado a partir de la realidad, pero con algunas consecuencias particulares; por ejemplo, muchas cosas que no proporcionaron placer alguno en la realidad, en el pasado, obtienen ese efecto en la fantasía.

Más que un juego de posibilidades, Freud subraya que el motor de esa actividad está constituido por los deseos frustrados y cada fantasía representará, inclusive, una realización de deseos -máxima potenciación- una rectificación de la realidad insatisfactoria (1954: 52).

Además, Freud subraya cómo, en el presente, un elemento desencadena la misma actividad rememorativa, en donde el valor de realidad no se convierte en criterio absoluto:

\footnotetext{
La fantasía flota, por así decirlo, entre tres tiempos, entre las tres coordenadas temporales de nuestra imaginación. El trabajo psíquico parte de una impresión actual, de un motivo en el presente susceptible de despertar uno de los grandes deseos que el individuo alberga; desde allí, toma enlace con el recuerdo de una vivencia pretérita, generalmente infantil, en la que el halló satisfacción, estableciendo así, imaginativamente, una situación -el sueño diurno, la fantasía- proyectada al futuro, satisfactoria del deseo y provista de signos que revelan su doble origen: el motivo actual y el recuerdo. Así, el pasado, el presente y el futuro se enhebran en el hilo del deseo que pasa a través de ellos (Freud 1954: 52- 53).
}

Se considera, por tanto que, una poderosa vivencia actual (lo cual coincide con la perspectiva de Rodríguez acerca de las situaciones de cambio) despierta el recuerdo de una vivencia pretérita. Freud agrega que, generalmente, ese recuerdo proviene de la infancia, lugar donde se origina el deseo que pretende satisfacerse mediante la "comunicación de la nostalgia" (en términos de Rodríguez):

[...] una poderosa vivencia actual despierta en el poeta el recuerdo de una vivencia pretérita, oriunda por lo general de la infancia, originándose en ésta el deseo que persigue su realización en la obra poética, la cual nos permitirá reconocer, tanto elementos de la motivación actual, como del antiguo recuerdo (Freud 1954: 55). 
Por otra parte, en el caso de la dimensión social de la nostalgia -donde recuerdos y fantasías se entremezclan- las relaciones interpersonales que ya no pueden ser reproducidas se revalorizan e inclusive convierten la nostalgia en un fenómeno de la soledad por la ausencia del otro valorado:

\footnotetext{
Se produce, por comparación, una sobrevaloración de las relaciones con personas ausentes en la que -como veíamos por el mecanismo de generación de la nostalgia- se complementa con la fantasía la falta de complejidad del recuerdo. También en este nivel se trata de reconocer que la relación social ausente tenía más posibilidades de las que fueron actualizadas y se lamenta el no haberlas agotado en su momento y no esta, aquí y ahora, en condiciones de hacerlo (Rodríguez; 1990: 19).
}

Sea a partir de esta faceta relacional, del elemento rememorativo ambiental o incluso individual, la nostalgia se plantea por Rodríguez como la reconsideración de posibilidades, a partir de un elemento de insatisfacción con el presente. Nuevamente apuntando hacia el elemento social, Rodríguez añade que una evaluación negativa de las relaciones sociales actuales, en comparación con las pasadas, desencadenará inclusive una reafirmación de la propia identidad (1990: 19); allí la labor de la nostalgia supera las dimensiones emocionales negativas para convertirse en instrumento emancipador.

Si además se considera la etimología de la palabra, el término griego nóstos (de: regreso, vuelta a la patria), así como el término en alemán heimweh, se entiende la necesidad de rescatar el asidero implicado en las imágenes pasadas. La patria será todo aquello que implique pertenencia, física o temporalmente: personas, lugares, acontecimientos; ergo, el enfrentamiento "patria"- memoria debería resultar en afirmación, de un "yo" o un "nosotros", tal cual lo plantea la nueva novela española cuando asume además de la actitud nostálgica, la vertiente autobiográfica ${ }^{4}$.

Sin embargo esta dicotomía espacial: acá/ allá, ha sido extendida, mayormente, a una relación temporal: antes/ ahora, ayer/ hoy; donde el ayer puede o no identificarse con un espacio concreto, pero siempre hay un componente de tiempo implícito; es decir, si la nostalgia surge originalmente como un problema del espacio, de las personas que se ven obligadas a salir de sus hogares, se transforma luego en un problema del tiempo (Rodríguez 1990: 23).

Pareciera que la relación tiempo y espacio establece así un dialogismo en la percepción nostálgica pues, de una u otra forma, los recuerdos evocados se asocian, en primera instancia, a determinado lugar. Ya el filósofo Gastón Bachelard había señalado la asimilación de una imagen con un recuerdo y -en consonancia con un concepto de nostalgia- examinaba las imágenes del espacio feliz (2000: 27), el cual se convierte en sede primordial del desencadenamiento de la memoria nostálgica.

De esta forma, la reconstrucción temporal, que acompaña el ejercicio de la conciencia nostálgica, se extiende tanto a categorías espaciales como temporales. El pasado se reconstruye mediante asociación de un espacio físico que se visualiza por la memoria, de forma retrospectiva.

Al respecto, Bachelard plantea el concepto de topofilia, como un intento por desentrañar el valor humano de ciertos "espacios de posesión de los espacios defendidos contra razones adversas, de los espacios amados" (2000: 28). Sea por la añoranza del espacio feliz, sus relaciones o experiencias, el individuo nostálgico se ve en la apremiante necesidad de abocarse sobre su pasado, en donde reconsiderará y extrañará las posibilidades anteriores.

En esta dirección, se desencadena la ambigüedad, pues para el lector que identifica un tópico de guerra o dictadura, resulta paradójico que se convoque la existencia de un espacio feliz. Sin embargo, desde el inicio Navajas subraya elementos que convierten esta época en un 
momento anhelado y esto se debe, principalmente, a la misma razón que esbozaba Rodríguez cuando advertía que remontarse al pretérito es potenciar toda una serie de contingencias (sociales o personales), que no han sido consumadas. de opciones:

Bachelard agrega el elemento del "valor imaginado" que concuerda con este juego

\begin{abstract}
Por razones frecuentemente muy diversas y con las diferencias que comprenden los matices poéticos, son espacios ensalzados. A su valor de protección que puede ser positivo, se adhieren también valores imaginados, y dichos valores son muy pronto valores dominantes. El espacio captado por la imaginación no puede seguir siendo el espacio indiferente entregado a la medida y a la reflexión del geómetra. Es vivido, no en su positividad, sino con todas las parcialidades de la imaginación (Bachelard 2000: 28).
\end{abstract}

La vinculación del recuerdo no solo con una circunstancia socio-histórica, sino también con un espacio físico, desencadenará de una u otra forma la sensación -que señalaba Darío Rodríguez- de preferencia por la situación anterior (situación personal o relaciones interpersonales); ante esta se presenta, en el hoy, un resultado que pretende ser negado, de alguna manera:

Un espacio percibido como más bello e íntimo que el actual pone de manifiesto por asociación un contexto humano que se consideraba como mejor porque provocaba la emergencia de cualidades que se han extinguido hoy (Navajas 1996: 52).

Si esta actividad rememorativa traslada al sujeto hacia su infancia, esta evocación se acompaña de imágenes (Bachelard 2000: 47) y estas serán asociadas a los lugares primarios de socialización: el pueblo y la casa natal.

Acudir a ese espacio físicamente y por la memoria es reencontrarse con un espacio íntimo, cuyo carácter es emotivamente entrañable, convirtiéndose, inclusive, en el espacio refugio (Cuvardic 1998: 99). De hecho, en La poética del espacio, se dice que la casa es "un cuerpo de imágenes que dan al hombre razones o ilusiones de estabilidad" (Bachelard 2000: 48). El recuerdo de la infancia será ubicado, inicialmente, en aquella casa, cuna de las evocaciones primordiales del individuo.

El concepto de nostalgia, al remitirse al pasado personal y por ende a los primeros años de vida de la persona, supone una apreciación subjetiva de aquella "región lejana" donde memoria e imaginación no permiten que se les disocie (Bachelard 2000: 35). Nos enfrentamos a un campo donde la ensoñación se entrecruza con la experiencia de múltiples formas.

La principal consecuencia radica en el cariz positivo y afectivo que se le otorga a las imágenes de la infancia (primera faceta de la nostalgia de la nueva narrativa española en su mirada hacia el periodo posterior 1936). A este tiempo anterior se le denomina "Edad de Oro", la etapa de seguridad, bienestar y cobijo:

\footnotetext{
De hecho, estamos aquí en la unidad de la imagen y del recuerdo, en el mixto funcional de la imaginación y de la memoria. La positividad de la historia y de la geografía psicológica no puede servir de piedra de toque para determinar el ser verdadero de nuestra infancia. La infancia es ciertamente más grande que la realidad. Para comprobar, a través de todos nuestros años, nuestra adhesión a la casa natal, el sueño es más poderoso que los pensamientos [...] Excepto algunas medallas con la efigie de nuestros antecesores, nuestra memoria infantil no contiene más que monedas gastadas. Es en el plano del ensueño, y no en el plano de los hechos donde la infancia sigue en nosotros viva y poéticamente útil (Bachelard 2000: 47. La cursiva es nuestra).
}

Pareciera que hay una imposibilidad en la determinación objetiva de los valores de infancia; en este sentido -tal como se mencionó anteriormente- el individuo se debate entre 
la ensoñación y la veracidad de sus recuerdos. Así, en el intento por aprehender la razón de la nostalgia por la infancia no se debe obviar el matiz poético inherente a las imágenes pasadas. Surge entonces la pregunta del por qué de esta sobrevaloración, el grado de veracidad o solidez del vínculo emotivo, o en palabras del Bachelard:

\footnotetext{
[...] ¿los hechos tuvieron el valor que les presta la memoria? La memoria lejana sólo los recuerda dándoles un valor, una aureola de felicidad. Borrado dicho valor, los hechos ya no se quieren. ¿Es que han sido? Una irrealidad se filtra en la realidad de los recuerdos que están en la frontera de nuestra historia personal y de una prehistoria indefinida en el punto precisamente en que la casa natal, después de nosotros, viene a nacer en nosotros (Bachelard 2000: 90- 91).
}

A partir de lo anterior, los textos en donde se rememora la infancia se encuentran matizados por un tono de apego y sentido de pertenencia. Nos enfrentamos, en primer lugar, a nostalgia por el espacio (la casa), las sensaciones (olores, sabores, sonidos, imágenes), y la familia.

No obstante, insistimos en el valor ambiguo de la nostalgia en el caso de la narrativa española de fin de siglo. Dado el contexto social en el cual se enmarcan los recuerdos personales enunciados en estas novelas (Guerra Civil y Dictadura), la nostalgia asume otra vertiente: la nostalgia asertiva, la cual complementará aquella búsqueda y reconocimiento que mediante el recuerdo- fantaseo procuraba la aserción individual.

Tras el rencuentro con el "lugar seguro" que ha permitido la reevaluación de aquellas potencialidades y el consecuente proceso de afirmación de la identidad de quien debe asumir, irremediablemente, su hoy, se procede al develamiento de los fantasmas sociales (los de antaño y los actuales); en consecuencia, mediante una comunicación nostálgica desmitificadora, se deriva la aserción colectiva.

\section{La nostalgia asertiva en la narrativa española de finales de siglo XX}

El crítico literario Gonzalo Navajas acude a este concepto de nostalgia como un mecanismo de acercamiento a la estética de la nueva novela y el cine españoles. Tras una numerosa producción artística caracterizada por el sinfín de rupturas de las propuestas posmodernas, Navajas propone la identificación de una nueva estética -y ética- presente en la novela y cine de los ochenta y noventa. Allí la nostalgia se convierte en uno de los elementos configuradores.

Si anteriormente el posmodernismo, además de propugnar una relación de rechazo y ruptura con cualquier noción de "pasado", abogaba por la indiferencia cognitiva y la irresolución (Navajas 1996: 21), la actitud nostálgica de la nueva novela supondría una revaloración del pasado; donde la aserción sobre este, reformula la indeterminación ética y estética posmoderna. Sin embargo, tampoco pretende asumir el programa de la fase miméticodidáctica de la novela española de los cincuenta y sesenta, donde privaría una función del texto vinculada con un programa social o moral "estrecho e inflexible":

\footnotetext{
La ficción española reciente actualiza la nueva configuración epistémica. Con ella se inicia la fase de la nostalgia asertiva de la novela de la década de los ochenta y los noventa. Esa fase se opone a dos fases previas: 1. La fase mimético- didáctica de los años cincuenta y sesenta, en que la novela se concibe como un tratado documental con un propósito informativo y pedagógico con fines y conclusiones precisamente identificables. 2. La fase posmoderna en la que el texto es un medio para experimentar lúdicamente con las posibilidades de ambigüedad y plurisignificación del lenguaje y la imaginación al margen de los modos convencionales (Navajas 1996: 109).
} 
De esta forma, la "nueva novela" ni se enmarca dentro de un programa ético rígido y propagandista, ni se diluye en la indeterminación axiológica; según Navajas, esta fase de la nostalgia asertiva implica, además del elemento ético, "una posición diferencial frente al tiempo pasado" y primordialmente ante la Guerra Civil y la dictadura franquista, como su característica distintiva.

En su ensayo "Una estética para después del posmodernismo: la nostalgia asertiva y la reciente novela española”, Navajas ya había señalado que si bien la visión de la nostalgia podía falsificar el mundo, esa falsificación aparecía como acogedora frente a un presente inhóspito para el yo (1993: 110). A partir de estas nociones, Navajas esboza cómo el descontento con el presente constituye una de las motivaciones principales del retorno nostálgico en la novela y el cine españoles; es decir, se trata del ennoblecimiento de un segmento del pasado, que "desde el presente aparece como cualitativamente mejor que el actual" (1993: 109).

La tematización del pasado por la nostalgia se convierte, para Navajas, en una especie de refugio "para una conciencia herida por la realidad del presente que ha desconfirmado inapelablemente la opción del cambio profundo" (1996: 52). En virtud del recuerdo y la reconsideración nostálgica de las posibilidades del tiempo pretérito, se revela la inconformidad del sujeto con su circunstancia y, a la vez, su determinación a definir la realidad, a partir de cuanto recrea el deseo y la imaginación, más que según el criterio de la razón.

En este sentido, la nostalgia no es solo recuperadora, sino revalorizadora. Dentro de estas categorías se ubicarían aquellos escritores que pretenden rescatar, por ejemplo, el heroísmo, el idealismo que prevalecía en los años de represión:

La valentía de la supervivencia cotidiana adquiere valores positivos frente a las decisiones y acciones del poder. El interés se centra en el heroísmo que no claudica ante la adversidad y tiene a la duda..., a la misericordia, y a la piedad como actitudes que es necesario recuperar (Cuvardic 1998: 146).

El espacio convulso de la Guerra Civil o de la posguerra, puede llegar a percibirse "como más bello e íntimo que el actual"; según Navajas, esto sucede en virtud de las asociaciones que sugiere "un contexto humano que se consideraba como mejor porque provocaba la emergencia de cualidades que se han extinguido hoy" (1996: 52).

Navajas agrega que para estos escritores la nostalgia se convierte en el refugio para una conciencia herida, cuando la opción de cambio profundo ha sido desconfirmada por la realidad del presente. Regresar, inclusive a la época de dictadura, resulta más gratificante que enfrentar el fracaso de los ideales forjados en aquel tiempo. Si bien se trata de una falsificación del mundo, el crítico agrega que esa falsificación aparece como acogedora frente a un presente inhóspito para el yo (Navajas 1996:52).

Coincide esta explicación del fenómeno de la nostalgia con cuanto señala Darío Rodríguez, al considerar el recuerdo nostálgico como una "reelaboración presente de los presentes pasados en la medida de la posibilidad" (1990: 14). Así, los textos nostálgicos, en ocasiones, rescatan hechos heroicos, matizados por la belleza y la nobleza, según la forma como opere el deseo sobre dichos recuerdos:

Desde la perspectiva nostálgica, el yo se sitúa en un medio envolvente irreal, entrañable y gratificante, en el que no se requiere la disciplina de la verificación racional o lógica del presentado. La nostalgia revela la ineptitud o impotencia del sujeto para definir coherentemente el mundo y una aceptación de que la realidad debe percibirse más como se presenta al deseo y a la imaginación que a la razón (Navajas 1993: 110). 
El criterio de subjetividad atraviesa el discurso de los narradores, puesto que se va más allá de la razón, según el juicio de la memoria histórica, para representar el recuerdo según la fantasía. No obstante, Navajas aclara que esta orientación nostálgica no opera como evasión hacia "edenes de artificio", pues se sabe efímero.t

Es decir, si bien el principio recuperador del pasado es, al mismo tiempo, un principio de revalorización motivado por un sentimiento nostálgico; dicho refugio se concibe como un proyecto temporal:

\footnotetext{
La nostalgia no es paralela ahora a la huida a edenes de artificio propia de otros momentos estéticos. El impulso nostálgico actual se sabe provisional - un paréntesis en el tiempo-y no ignora que está destinado a retornar al presente y no a negarlo resueltamente. En ese retorno hay incluida una posibilidad de mejoramiento personal porque la conciencia se ve expandida y profundizada después de una jornada por los caminos de la rememoración o reconstrucción de la imaginación añorante (Navajas 1993: 112).
}

La función de la nostalgia, a partir de esta dimensión, incluiría una posibilidad de mejoramiento personal, una vez que se retorna de los caminos de la imaginación añorante, el pasado se ha reinterpretado para dialogar con el presente, ya sea por el restablecimiento de valores pretéritos o por la redinamización de la circunstancia en el hoy.

Dichas afirmaciones, permiten identificar cómo para Navajas, al igual que para Darío Rodríguez, el proceso de recuperación nostálgica de un segmento del pasado libertará una asertiva autoafirmación, donde si el presente resulta incapaz de satisfacer las expectativas, al menos la actitud nostálgica permite la configuración en el pasado de diversas formas de realización humana que en el hic et nunc conlleven alguna mejoría o reconciliación personal.

Ahora bien, retomando el principio de retorno nostálgico desde la concepción del pasado como Edad de Oro, por su identificación con el tiempo de infancia y juventud, la nostalgia asertiva apunta al desenmascaramiento de los recuerdos; precisamente por la constatación de que dicho segmento no resultó gratificante.

Los recuerdos de infancia son ennoblecidos por la memoria, cuyas trampas disfrazan de fantasías las realidades y de realidades las fantasías. Sin embargo, la infancia también determina al individuo, en el plano de las experiencias negativas y un contexto de guerra o dictadura o una circunstancia de agresión en el ámbito privado, manifestarán su grito de discordia en el acto rememorativo. Señala Cuvardic cómo el miedo, presente en el ser humano, se origina en la infancia y la narrativa de la nostalgia asertiva ejecuta, de ese modo, la recuperación de las manifestaciones originarias del miedo por medio de la nostalgia dolorosa (1998: 146).

Por este concepto, pueden esbozarse las implicaciones de la nostalgia asertiva, vinculada siempre a ese cariz de recuerdo "doloroso". Para Cuvardic, en los escritores de la nostalgia asertiva se comprueba que la infancia no es quizás una Edad de Oro, un paraíso perdido que es necesario recuperar.

Mediante dicha toma de conciencia, la infancia se convierte en el espacio elegido por el escritor para ensimismarse e iniciar la escritura de denuncia o la escritura desmitificadora (Cuvardic 1998: 158).

Esta postura de crítica y desenmascaramiento será una de las principales vertientes de la nueva narrativa española, y será identificada como nostalgia asertiva. Para los lectores de la narrativa española de finales de siglo cobra sentido esta intención de denuncia del período de la Guerra Civil y la posterior Dictadura, como una época de sufrimiento, injusticia, y explotación de las libertades del hombre. 
Dicha asertividad será interpretada a partir su valor de afirmación, en cuanto supone la actitud del yo que se sobrepone a un pasado traumático (desde la connotación etimológica de

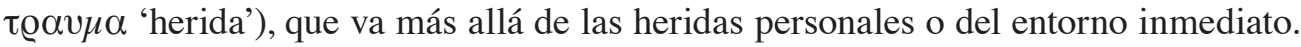

Ya no se trata de un retorno al Edén, de un refugio acogedor para el individuo nostálgico; más bien, la labor desmitificadora de la vertiente asertiva enfrenta los paradigmas de poder de las estructuras dominantes, según una posición subversiva y crítica, y estos se sustentan tanto en el espacio público, como en el privado.

De esta manera, se plantean otras formas de comunicación de la nostalgia, donde el fenómeno no constituye un sentimiento de rememoración emotivamente positivo sobre el pasado, sino más bien un mecanismo de desmitificación, denuncia y hasta liberación de los recuerdos y fantasmas que, desde el pasado, aún atormentan y condicionan al individuo en el hoy.

La nostalgia en el texto ingresa en una corriente cuya estrategia de narración se vincula con la memoria histórica (hechos padecidos por una colectividad) y personal. Al respecto, Girona, citada por Adoración Sales, señala la existencia de un grupo de obras que legitiman la memoria como fuente de hechos, así como su autoridad para conservarlos e interpretarlos (2000: 416- 417). La memoria en su faceta histórica y personal atraviesa el discurso nostálgico, desde la perspectiva de la víctima que pretende desenmascarar a su verdugo, denunciándolo y sobreponiéndose a este:

\footnotetext{
Y es la memoria, como veremos, lo que vertebra liminarmente esta novela de Traba. La memoria de los hechos, de los nombres, del horror, ante la doliente necesidad de recordar el pasado en un presente invisible, angustioso, impotente, pero, también, resistente, porque no olvidemos, como escribió Galeano, que "toda memoria es subversiva, porque es diferente" (1971: 470). Y junto a la memoria, el problema del olvido, necesario cuando el dolor se hace insoportable, rechazado cuando es sinónimo de "desaparición" (Sales 2000: 416).
}

La revisión de los recuerdos infantiles no exime el entorno socio-político, y aquella Edad de Oro es, esta vez, examinada desde una perspectiva crítica desde la cual se pretende desentrañar los sufrimientos escondidos en la experiencia de crecer en época de guerra y dictadura.

El acercamiento nostálgico, definido como tal por esa actitud de reconsideración del pasado, corresponde a un proceso desmitificador; se trata de "un implacable ejercicio de la memoria que acaba por ser la terrible crónica de una frustración, la sufrida por quienes vivieron su juventud en la España del franquismo" (Cuvardic 1998: 4).

Esta nueva postura de la nostalgia supondría, ya no un anhelo por lo acontecido o soñado, sino más bien un camino de desenmascaramiento donde el escritor, desde su vida adulta, enfrenta su infancia y juventud enmarcándolas en un trasfondo concreto (sociopolítico), más allá del ámbito privado y familiar:

\footnotetext{
Desde el presente, las experiencias del franquismo no se viven o se sufren: se recuerdan; el ser humano no se enfrenta a la complejidad de los contextos del franquismo; por el contrario, el recuerdo los esquematiza, los idealiza o los demoniza. En consecuencia, la desmitificación neofabuladora tiene por objeto desenmascarar el malentendido del recuerdo, la mitificación de lo recordado (Cuvardic 1998: 7).
}

La nostalgia, como trabajo de la memoria, asume un proyecto de relectura histórica de la violencia de la Guerra Civil y de la represión de la política del franquismo, pues se considera que sus influencias no han sido destruidas por el tiempo y el presente debe enfrentarlas, incluso como las posibles causas de degradación de la democracia, donde las contradicciones entre el poder político y económico frente a lo social perviven: 
En el marco de esta situación social, los escritores de la nostalgia asertiva critican tanto el franquismo como la democracia: los proyectos del franquismo (grandeza) y de la democracia (justicia) se revelan ilusorios (Cuvardic 1998: 127).

Es decir, cuando el sujeto retorna sobre su infancia, reconociendo que quizás no fue la Edad de Oro que el imaginario forjó, implícitamente emprende un proceso de liberación de las secuelas del dolor y temores propios de esa época. Esta aserción le permite no solo sobreponerse a su pasado, sino también comunicar su experiencia y colaborar con la interpretación de la historia común, para que de alguna manera la memoria histórica sea también aleccionadora.

\section{Conclusiones}

Desde su etimología, el valor de la nostalgia supone un movimiento entre la patria y el exilio. Es plausible que junto al rechazo aparezca el anhelo, junto a las fobias, las filias; es decir, el sujeto se debate entre el recuerdo doloroso y el recuerdo afectivo y dicha paradoja acompaña las diferentes vertientes que el fenómeno nostálgico puede asumir en el conjunto de la novela española de finales del siglo XX.

Por un lado, se habla de la extinción de las grandes causas en el presente y su fuerza en el pasado (Navajas 1993: 115- 116), idealismo y lucha que en el desentendimiento conformista que caracteriza a las sociedades actuales, se presenta como un naufragio del heroísmo y el valor de las personas.

Unido a esto, se habla de la época de infancia como de la eterna Edad de Oro, refugio seguro ante las inclemencias de la vida adulta y, por ende, tesoro y castillo que muchos se resisten a dejar por completo; o bien aquel lugar donde se reúnen las primordiales señas o motivaciones de su propia identidad, que en ocasiones no siempre se asimilan a recuerdos o relaciones felices.

Finalmente, la época es identificada por su crueldad, injusticia, violencia y degradación. La guerra o la explotación de un régimen de dictadura deben ser enfrentados y considerados desde un juicio, un desenmascaramiento, una puesta en evidencia -o en entredicho- por parte de sus propias víctimas.

El escritor nostálgico debe reconocer, en su retorno, las coordenadas -históricas- en las cuales se ha desenvuelto su propia circunstancia; puesto que no puede aislarlas. Para los autores de la narrativa española de fines de siglo esta tendencia de "evasión" a la casa natal es encuentro con los seres queridos o no tan queridos, pero también con una ciudad, con un estado convulso de las cosas y con una ideología dominante y arbitraria.

La amalgama de experiencias que determinan al sujeto se traslada intermitentemente del interior hacia el exterior, del ámbito privado al ámbito público. Así, la imaginación creadora ha debido acudir a los espacios del pasado una vez superado el "pacto de olvido" tras la muerte de Franco, una vez padecido el llamado "desencanto democrático"; pero, sobre todo, una vez que los narradores confiesan en sus textos una necesidad personal y colectiva de reconciliación, conocimiento y afirmación en el hoy.

\section{Notas}

1. Dicho fenómeno ha trascendido el ámbito español y se ha manifestado, inclusive, en el ámbito latinoamericano; de hecho, la temática del pasado -y un tiempo de guerra y dictadura- aparece, también en el contexto de la novela argentina de los años ochenta. Para Nuria Girona (Sales 2000: 416- 417), varios narradores realizaron escrituras, mejor reescrituras de la historia como testigos de la última 
dictadura argentina (1976-1983), desde la literatura se plantean distintas propuestas narrativas en las que es posible vocear lo que el discurso histórico calla, lo que la versión oficial niega.

2. Samuel Amell, señala la relación entre pasado de España y memoria en varios autores de la década de los ochenta; por ejemplo, Marsé usa de la memoria tanto personal como colectiva en sus siguientes novelas Un día volveré y Ronda del Guinardó; otros también tratan de la España de postguerra y en ella la memoria vuelve a desempeñar un papel crucial. Las novelas de Jesús Fernández Santos, Carmen Martín Gaité y Francisco Umbral usan España como temática y la memoria como instrumento para hacer llegar aquella al lector (1987:190-191).

3. Cuvardic define la memoria histórica como "ese imaginario histórico que, procedente de una generación, de un colectivo de seres humanos, es asumido como herencia cultural por las nuevas generaciones" (1998: 7). Existe incluso la llamada Asociación para la Recuperación de la Memoria Histórica, formada por la Izquierda Unida y el Partido Socialista Obrero Español quienes presentaron formalmente al Congreso de los Diputados, del 9 de septiembre al 4 de octubre de 2002 sus proposiciones a favor de la no reivindicación de las víctimas del franquismo.

4. Varios críticos, entre ellos Navajas y Tortosa (2001) señalan la emergencia de la narrativa autobiográfica como una de las tendencias de la narrativa española de la era democrática. En la Tesis "Luna Lunera como testimonio de la posguerra española: estrategias de retorno nostálgico del yo femenino” (2004), la autora de este artículo analiza este fenómeno.

\section{Bibliografía}

Amell, Samuel. 1987. "La novela española española de los ochenta: resultado de una trayectoria definida”. Revista de Occidente. 17 (37): 185- 192.

Bachelard, Gaston. 2000. La poética del espacio. Madrid: Editorial Fondo de Cultura Económica.

Cuvardic, Dorde. 1998. La desmitificación nostálgica neofabuladora de la nueva narrativa española en Beatus Ille, de Antonio Muñoz Molina. Tesis Maestría en Literatura española: Universidad de Costa Rica.

Dolgin, Stacey. 1991. La novela desmitificadora española (1961- 1982). Barcelona: Editorial Anthropos.

Encinar, Ángeles. 1990. Novela española actual: la desaparición del héroe. Madrid: Editorial Pliegos.

Freud, Sigmund. 1954. Obras Completas: Psicoanálisis aplicado. Tomo XVIII. Buenos Aires: Amorrortu Editores.

Gullón, Ricardo. 1994. La novela española contemporánea. Madrid: Alianza Editorial.

Jameson, Fredric. 1998. Teoría de la Postmodernidad. Madrid: Editorial Trotta. 
Navajas, Gonzalo 1996. Más allá de la modernidad: estética de la nueva novela y cine españoles. Barcelona: Ediciones Universitarias de Barcelona.

Pereiro, Peregrina. 2002. La novela española de los noventa: alternativas éticas a la Postmodernidad. Madrid: Editorial Pliegos.

Rodríguez, Darío. 1990. “Acerca de la Nostalgia”. Revista de Estudios Sociales. 66 (4): 11- 28.

Senabre, Ricardo. 1995. “La novela española, hacia el año 2000”. Letras de Deusto. 25 (3): 23-38.

Serra, Fátima. 2000. La nueva narrativa española: tiempo de tregua entre ficción e historia. Madrid: Editorial Pliegos.

Sobejano, Gonzalo. 2003. Novela española contemporánea 1940-1995. Madrid: Mare Nostrum Comunicación S.A.

Todorov, Tzvetan. 1975. Poética. Buenos Aires: Editorial Losada.

Tusell, Javier. 1977. La transición española a la democracia. Madrid: Historia, SL.

Vázquez Montalbán, M. 2001. La literatura en la construcción de la ciudad democrática. Barcelona: Grijalbo Mondadori S.A. 